\title{
Feminist mobilisation for policy change on violence against women: insights from Asia
}

\section{Paola Cagna and Nitya Rao}

This article explores how women's movements in China, India and Indonesia have mobilized to influence processes of legal reform on violence against women (VAW). Legal change is a complex and iterative process, in which both state and non-state actors negotiate and bargain over the content of law in the 'policy space', bringing different interests and needs to bear. The three countries featured here differ in many ways, including population size, political system (including varying levels and degrees of democratization and decentralization, and regional and local autonomy), and diversity in the population, including ethnicities and religions. A comparative study such as this offers important potential for understanding policy change on VAW, the role of women's movements in this, and the obstacles to change.

Keywords: violence against women, legal reform, China, India, Indonesia, women's movements, policy space

\section{Introduction}

Today, addressing violence against women is a key priority in the international community, and countries in both the global South and North. An increasing number of laws and policies to eradicate violence against women have been adopted, although progress remains uneven. At the moment of writing, the latest country to legislate on this issue was China, which criminalized domestic violence at national level in December 2015. For decades, women's movements have been raising the profile of violence against women in political and public discourse, and they continue to have a strong influence on legal and policy changes (Htun and Weldon 2012). However, women's movements are not the only agents of change, in spite of their crucial role (Mazur 2002). Other actors within and outside the State compete with women's movements to influence or hinder change, to define the content of new policy and legal frameworks, and therefore determine what political demands or claims are included in the final text (Franceschet 2010).

A nuanced analysis of policy and legal change reveals that these processes are highly complex. The comparative analysis we offer here of women's mobilization on violence against women in China, India, and Indonesia, contributes to understanding this complexity. The article draws on findings from a research project titled When and Why do States Respond to Women's Claims? Understanding Gender-Egalitarian Policy Change in Asia. The research took place between 2013 and 2016. It was co-ordinated by the United Nations Research Institute for Social Development (UNRISD), and funded by Ford Foundation. It was conducted in collaboration with the Women's Studies Institute of China, the Institute of Social Studies Trust, India, and the Semarak Cerlang Nusa Consultancy, Research and Education for Social Transformation, in Indonesia. 
Following a brief overview of the research design, the first section of the article will outline our arguments on the processes of change and law-making around VAW, exploring what makes it such a complex undertaking. The second section will explore why certain women's claims related to violence against women succeed, while others remain excluded from the legal reforms in the three countries. The last section will analyse the different strategies for successful bargaining, based on evidence from the case studies.

\section{Research design: an overview}

China, India, and Indonesia, the countries of our study, all offer insights significant for understanding broader processes of change around violence against women, because of their size, governance systems with regional and local autonomy, and other forms of diversity in terms of ethnicity, religious beliefs, and livelihood contexts.

The research mainly focused on women's collective political action at national level; in particular, mobilization for the approval of the laws on domestic violence in China (the Domestic Violence Law, 2015) and in Indonesia (the Law on Domestic Violence, no.23/2004). For India, the article analyses the mobilization of women around the amendment of the sections on sexual assault in the Indian Criminal Law (specifically, to the Criminal Law [Amendment] Acts of 1983 and 2013). UNRISD research reports are forthcoming on each of these, and we draw extensively on the findings within them [2].

In addition, we drew on experiences at subnational levels [3]. Women's movements can direct claims toward both central governments, and provincial or state governments. India and China are federal countries and Indonesia has a decentralized system, meaning that legislative power is shared between the central government and the governments of the provinces (China, Indonesia) and of the states (India). Research was conducted in the Chinese provinces of Hunan and Shaanxi, in the Indian states of Gujarat and Karnataka. In Indonesia, it included both provincial and district levels: the provinces of East Java, West Nusa Tenggara, and West Sumatra; and the districts of West Pasaman, Jember, and East Lombok.

To assess the complexities of change processes at both central and subnational levels, each case study identified the following:

1. key actors engaged in the mobilization (for example, women's organizations, political parties);

2. key events (that is, specific cases of violence against women that might have been catalysts for the mobilization);

3. key strategies (for example, national networks, or use of mass media).

Interviews with key informants (policy makers, bureaucrats, lawyers, and activists), were supplemented by archival research (parliamentary debates, policy documents, judicial reports). In the case of Indonesia, the research was also an exercise in self-reflection, focusing on the 
researchers' personal experiences of activism, since they had been directly involved in mobilization for the law on domestic violence. This article draws on the accounts, opinions and views of many informants involved in the research.

Contrary to what is sometimes assumed, laws result from complex processes of negotiation and bargaining, among a wide range of actors (Gaventa and McGee 2010). These actors include state institutions, of course, but also many different constituencies from civil society. Each of them represents different political interests, and has different claims based on those interests.

Therefore, the law-making process can be seen as a struggle over what demands to include, and how to interpret the meanings and content of these demands (Fraser 1989).

Such processes of bargaining and negotiation between state and non-state actors develop within what can be called the 'policy space'. We find this a useful concept. Policy space has been defined by John Gaventa $(2006,26)$ as 'opportunities, moments and channels where citizens can act to potentially affect policies, discourses, decisions, and relationships that affect their lives and interests'. This is a dynamic space, which can be expanded, contracted, opened up or closed down. Within it, different actors discuss and contest their interests and demands. Importantly, and to add to the complexity, the policy space is not only a place for negotiation between state and nonstate actors, but also amongst different non-state actors - and indeed between different state actors, since the state is not a single entity.

The country studies demonstrate the complexities involved in three specific law-making processes on violence against women. The Indian Criminal Law (Amendment) Act of 2013 was the outcome of a long history of negotiation, which started in the late 1970s. This involved women's organizations, LGBTI groups, law commissions, and the Indian parliament. In Indonesia, women activists negotiated over almost a decade with religious leaders, human rights organizations, profeminist men's groups, and ultimately with Parliament members and policy makers to secure the content of the Domestic Violence Law, no.23/2004. The Chinese government approved the Domestic Violence Law, 2015, after twenty years of pressure from the All China Women's Federation (ACWF), autonomous women's organizations clustered in the Anti-Domestic Violence Network (ADVN) [3], and international organizations. Although women's movements did play a key role in leading and framing mobilizations on violence against women (Htun and Weldon 2012), they constantly negotiated with other constituencies, who also influenced the process of change. In all three countries, gains were made through lengthy, negotiated and complex processes.

Women's movements themselves are not homogenous. On the contrary, they are segmented along other lines, including class, sexual identity, caste, religion, ethnicity, and geographical origin (for example, urban versus rural). So, during processes to negotiate for legal reform, women's organizations also negotiate demands and claims among themselves. Examples of this can be seen in our country studies. While building a national alliance to advocate for the law on domestic violence, Indonesian women's groups bargained with religious women's organizations. In India, in the late 1970s and early 1980s, women's organizations overcame different ideologies, as well as 
differences of caste, class, geographical origin, and religion through national consultations to agree on their demands. The autonomous women's organizations that flourished in China after the Beijing Conference in 1995 mirrored the need of sections of the Chinese women's movement to dissociate from the ACWF, and create new spaces for activism and advocacy (Du et al. 2015).

As we have said, the state is not a single entity, and a variety of state actors are engaged with the law-making process on violence against women. These include political parties, women's national commissions, ministries, and women politicians' caucuses. The different state actors operate at different levels of the process, and can adopt contradictory opinions over the same issue particularly in federal and decentralized countries.

Again, this is exemplified in the three case studies. The Indonesian National Commission on Violence against Women faced resistance from most of the members of Parliament to the national law on domestic violence. Similarly, in 2013, the Indian Parliament rejected the most progressive recommendations for reforming the laws on sexual assault proposed by the technical commission (known as the Justice Verma Commission), which was appointed by the government in 2012. The Chinese People's Congress approved the national law on domestic violence a full 15 years after Hunan province, the first local government in China, approved a resolution on the issue (in 2000), progressively followed by 21 other provinces. So even when women's claims are effectively channelled into the state, they undergo a further process of bargaining, among different state actors, and at different levels of governance.

Finally, there is complexity in the way policy spaces are constituted. These spaces are embedded in power relations; actors do not enjoy equal access, voice or influence over the policy space (Cornwall 2002). At one level, institutional mechanisms might prevent certain actors from accessing the policy space (for example, lack of access to parliamentary discussions). At another level, more subtle manifestations of power work to value or devalue particular actors and their demands. LGTBI [4] groups, for example, may be present in the policy space, but their voices often remain at the margins of policy-change processes on violence against women.

Throughout the policy process, power is exercised. Powerful actors are able to keep certain issues, like marital rape, off the political agenda (Eyben 2012). In almost all countries, the majority of parliamentarians are men [5] - a particular issue when violence against women is debated. Violence against women is seen widely as part of the natural order of things, hence challenging it includes a process of raising awareness that it is an issue of rights, and the perpetrators are guilty of a crime.

\section{When and why are women's claims adopted by the state?}

Our research was prompted by the fact that successful mobilization on violence against women has contributed to progressive legal change across countries. For instance, the latest reform of the 
Indian Criminal Law has expanded the definition of rape to include penetrations other than penovaginal, to include objects, and oral sex without consent. Crimes such as stalking and acid attacks have also been recognized. In China, the law on domestic violence has recognized this as a nationwide problem, not just restricted to a few provinces. It also covers both married and unmarried couples, and people sharing a living space but unrelated, including foster families and live-in domestic workers. The Indonesian Law on Domestic Violence, no.23/2004, adopted the definition of domestic violence (including psychological, physical, sexual and economic abuse), and measures for the protection and assistance of victims, as suggested by the women's movement.

Despite these gains, however, in all three countries some claims have remained excluded from the reform. In India, the recent reform excluded claims around the criminalization of marital rape demanded by women since the late 1970s - as well as the demand to include gender neutrality of both the victim and the perpetrator of sexual offences in legal texts, to avoid reproducing the idea of rape exclusively as an act by a man towards a woman. In Indonesia, the law on domestic violence adopted a limited definition of 'family' based on the Marriage Law no.1/1974, and excluding the marriages that are not registered with the State and co-habitations. Further, when women activists in Indonesia began to mobilize for a law on sexual offences and assault outside the domestic domain, they encountered a lot of resistance, as these demands opened up a controversial debate on women's morality and autonomy (Eddyono et al. 2016). In China, the recently approved law on domestic violence does not include sexual violence in its definition of domestic violence, and does not cover same-sex couples. The exclusion of these claims excuses and normalizes the forms of violence that are not under the purview of the law (Merry 2011).

The way that consensus-building between different constituencies works might explain why some claims are pursued, while others are not. To achieve the consensus required between different actors involved in political action, claims that are seen as more controversial are often left out in favour of those which are less divisive. This type of compromise can be actively used by advocates as a pragmatic strategy to push ahead with some demands, especially given political expediencies like elections. The more controversial claims then remain on their agenda for future mobilization.

From our case studies, we have several examples where such bargaining took place. In 2004, when the parliamentary legislature was coming to an end without approving the law on domestic violence, Indonesian women activists compromised on the demand for a broader definition of family, amongst others, instead of risking having to start the process of mobilization again with a new parliament and, maybe, a government with a different view on the issue of domestic violence (Eddyono et al. 2016).

In a series of meetings in 2010 and 2012, Indian women's and LGBTI organizations compromised to demand that the gender of the rape perpetrator in the Criminal Law should be specified as male, but the gender of the victim should remain unspecified. They could have made a more controversial demand that both victim and perpetrator should remain gender-neutral, but holding back from this ensured that the less contentious demand was passed (Chigateri et al. 2016). 
Similarly, the Justice Verma Commission made several progressive recommendations to the Indian Parliament (Ibid.). While not all were passed, they were at least brought into the discussion, even if ultimately rejected. Given the iterative nature of the process of policy change, these claims, already documented, can inform the next phase of women's mobilization, probably with a better chance of success.

Claims which affect all women - as claims about violence against women obviously do - lend themselves to support and solidarity among women and women's organizations. This was borne out by our research findings - for example, within the national networks against domestic violence in China and in Indonesia, as well as the cohesion amongst Indian women's organizations in the early stages of the mobilization.

In contrast, the claims in the case studies that were more contentious were claims that challenged traditional and commonplace norms about family and sexuality, with their roots in patriarchy and heteronormativity (that is, a belief that heterosexuality is the only, or 'normal' sexual orientation). These claims were what Mala Htun and Laurel Weldon $(2010,210)$ have defined as 'doctrinal' claims - that is, they are claims that challenge cultural norms and religious beliefs. The examples in our research of demands to include same-sex couples in laws on domestic violence, and to adopt a definition of rape in which victims are not only female (and still more contentiously, suggesting perpetrators are not only male), challenge traditional ideas about family structures and relationships, and sexuality. These claims are more likely to face resistance in policy spaces, and are also more difficult to organize around since they are not universally accepted by all actors seeking change.

Finally, whether claims are taken up or excluded also depends on where they fall in people's perceptions around the dichotomy between the public and private spheres. Breaking the silence around violence against women is an act of breaking the boundaries between private and public. It is often taken for granted that any form of abuse by the husband towards his wife is justified or to be solved within the privacy of the family. In India, rape is often associated with discourses of honour, shame, and blame. These discourses push the gender dimension of violence back into the private sphere and resist attempts from the state to intervene. The recent legal reforms in the case study countries proves that violence against women has entered the public domain, questioning some of the ideas around the private. However, claims relating to the criminalization of marital rape are still resisted by some in civil society as well as state institutions, as they ask the state to legislate against men's privilege within the family.

\section{Strategies for successful bargaining: insights from Asia}

In our study, we could see how women's movements mobilizing on violence against women used a variety of strategies to engage in negotiation and bargaining around their claims, in order to successfully influence the process of change. Different strategies were used depending on 
whether they were negotiating with other women's organizations, civil society, state actors, or international and transnational organizations. Informants in the research shared their perceptions of the usefulness of these various strategies and the sections below are informed by their assessments.

\section{Within the women's movement}

The key strategy was to build alliances among women's organizations, whether it took the form of networks (Indonesia and China) or national consultations (India). In each case, it strengthened the voice and the presence of the women's movement. The Indonesian leader of the mobilization against domestic violence, the Women's Association for Justice and Legal Aid (LBH APIK) established the Advocacy Network to Eradicate Domestic Violence (JANKGA PKTP) in 1997 (Eddyono et al. 2016). In China, a group of autonomous women activists created the AntiDomestic Violence Network (ADVN) in 2000 (Du et al., 2015). The presence of well-known activists as leaders facilitated the expansion of the network to other autonomous women's organizations, individual activists and scholars, as well as to Women's Federations at provincial and municipal levels.

Within these alliances, however, women's organizations have to reach a consensus on the claims to raise. Consensus requires negotiation and confrontation between the different interests and ideologies of the women's organizations. As mentioned, women are not a homogenous section of the society. Achieving consensus also means that some voices will prevail over others.

An important strategy in the face of such difficulties is to appeal to the similarities among women, as happened in India. For instance, the clause on the burden of proof (which specifies whether the victim or the accused must prove that a rape happened) was debated at length at the national conference, Perspective for Women's Liberation Movement in India, held in Bombay in 1980 (Patel, 2012). In the decade that followed, New Delhi-based women's organizations argued for applying the burden of proof to the accused for all cases of rape. This was opposed by women's groups from other Indian states who had suffered greatly from state repression during the Emergency [6]. They argued that the clause should only apply to cases of custodial rape. They feared that, if expanded to all cases of rape, the clause could be misused by the state to involve male activists in fake cases of rape. Another divergence was on the experience of sexual violence by women from different castes. Lower caste women experienced rape by husbands, landlords, and employers as part of their daily life, and saw it as an element of caste and class oppression; while upper caste women saw violence more as an exceptional experience. However, despite these differences, a consensus was finally achieved on the basis of their shared values: the dominance of men, the patriarchal state, and the caste and class systems over women as the root cause of sexual violence (Kumar, 1993).

A further strategy within the women's movement was to exploit the differences between different levels of women's organizations. For example, in China, collaboration between the ACWF and the ADVN was challenging, because the ACWF is very close to the Chinese Communist Party, while the 
ADVN is constituted by autonomous organizations who are often in conflict with the party. At the national level, being close to the centre of power, it proved politically difficult to overcome these differences. However, at the provincial and municipal level, where such power relations are less fraught, and members of the two organisations may have personal relationships, the network successfully co-ordinated with the Women's Federations, using their strong relations with the party to influence policymakers (Du et al., 2015).

\section{Building wider civil society support}

Women's movements employ a series of strategies to negotiate support from other organizations and movements. The purpose is to bring demands on violence against women into the public domain, and obtain broad-based civil society support for this purpose.

Broad alliances with different constituencies were important, especially in Indonesia. Our research revealed that the JANKGA PKTP network built a very wide-ranging alliance by opening up to human rights organizations, political parties, and religious leaders across the country (Eddyono, 2005). The New Men's Movement, a pro-feminist men's organization, also joined the network, confirming the importance of seeking men's support in eradicating domestic violence. The network also used champions within political parties and religious organizations to channel their claims into and gain the support of these organisations. For instance, some activists of the JANKGA PKTP were members of the religious organization Fatayat-NU [7] and were able to advocate for the urgency of a law against domestic violence, overcoming the scepticism of male religious leaders. The establishment of broad alliances with the civil society was less influential in India, where women's organizations coordinated with LGBTI and child rights movements only (Chigateri et al. 2016), and in China, where the mobilization was only supported by human rights organizations (Du et al. 2015).

Our research revealed that in Indonesia, women's organizations also sought to dialogue with potential opponents, such as customary leaders (Eddyono et al. 2016). In 2012-2014, women's and child rights organizations collaborated to stop the kidnapping and rape of young girls in the province of East Lombok. The perpetrators tended to justify their actions through the customary practice of elopement, known locally as merariq. However, merariq is consensual rather than being a forced kidnapping. To avoid conflict between the interests of those seeking to preserve customary practices and women's and girls' rights, activists convened meetings with the local government, customary leaders, and religious leaders to together find solutions to keep the practice but avoid its misuse. After a series of meetings, the government proceeded with the discussion of a by-law (Ibid.).

To gain broader support from civil society, women's movements need to frame their demands to fit with the discourses of other constituencies. In Indonesia, Muslim feminist women used the Quranic principle of the sakinah family - honest and peaceful family - to convince their leaders of the need to mobilize for a national law (Aisyiyah 2014). By contrast, Indian women framed their 
claims against sexual assault based on women's bodily integrity and autonomy (Menon, 2014), this might explain why the Indian movement was less supported by religious organizations.

Key events can be a catalyst for massive mobilization and/or for putting ongoing mobilizations in the spotlight, raising both awareness and support. In India, the rape cases of Mathura and Rameeza Bee in the late 1970s (Kumar, 1993) and the rape of a female student on a bus in New Delhi in 2012 triggered women's mobilization and massive demonstrations (Chigateri et al. 2016). In Indonesia, mass sexual violence against women of Chinese ethnicity during the 1998 riots [8] placed the topic of violence against women firmly in the public eye, and led to the National Commission on Violence against Women being established. In 2012, the Chinese public started to be aware of the story of Li Yan, a woman victim of domestic violence who was sentenced to death for murdering her husband, although she had regularly reported the abuse, but in vain (Guardian, 28 January 2013, http://www.theguardian.com/world/2013/jan/28/chinese-officials-domesticviolence). The sentence was overturned in 2014, after pressure from Chinese women's organizations, human rights groups, and international organizations. In the opinion of informants involved in our research, the case created opportunities to discuss domestic violence in public and was decisive for placing the issue in the five-year legislative plan of the Chinese government (Du et al. 2015).

Mass and social media give visibility to these key events, and provide a space for women's movements to raise their claims. Media can be a powerful tool to raise societal awareness on violence against women. For instance, the ACWF cooperates with the China Central Television Movie Channel to show advertisements against domestic violence (Du et al. 2015).

\section{Putting claims onto the state's political agenda}

In our research, we were able to identify a number of conditions which seem conducive to women's claims being placed on the political agenda.

A democratic regime provides an enabling environment for women's movements. We particularly see this in Indonesia, where the democratic transition at the end of the 1990s reinstated civil rights and introduced new mechanisms for increasing civil society participation - that is, organized groups could propose bills directly to the Parliament or through political parties (Blackburn, 2004). This new scenario appears to have facilitated the Indonesian women's movements and their mobilization to criminalize domestic violence. In India, democracy takes the form of public consultations such as those organized by the Justice Verma Commission (WSS, 2013). The Commission invited civil society to make recommendations on the issue of legal reform, receiving more than 70,000 submissions

http://www.prsindia.org/uploads/media/Justice\%20verma\%20committee/js\%20verma\%20commi tte\%20report.pdf, 20). In China, in spite of living in a (semi-) authoritarian regime, women's organizations were able to mobilize to some extent and to channel their demands autonomously or through the ACWF. 
A strategy adopted across the three countries was channelling claims to the state through women's national machineries or commissions, which proved effective in building bridges between women's organizations and the executive and legislative bodies of the state. In 2002-3, the Indonesian National Commission on Violence against Women planned a series of activities together with the JANKGA PKTP to gain the support of Parliament members. In interviews conducted during the research, we were told how they set up an Information Desk on domestic violence accessible to all members of parliament and other state officers. The Commission networked with the parliamentary women's caucus, enrolling them as champions within political parties and technical commissions (Eddyono et al. 2016). In 2010-12, the Indian National Commission for Women started negotiating the amendment to the Criminal Law, submitting a draft bill to the Indian parliament based on women's claims emerging from a series of consultations (Chigateri et al. 2016). In China, the ACWF to some extent played a similar role to the Indian and Indonesian commissions, attributable to its closeness and de facto affiliation with the Communist party (Du et al. 2015). For instance, in 2008, the Federation produced the first national policy paper on domestic violence together with six different state bodies (including the Ministries of Civil Affairs, of Justice and of Health). Through such collaboration, the Federation was able to include definitions of domestic violence and other claims previously raised by autonomous women's organizations (Ibid.).

Not only women's national machineries, but also personal relationships with policymakers and bureaucrats, can help women's movements channel their claims. In China, relationships with members of the political elites are seen by activists involved in our research as essential in order to have influence (Du et al. 2015). The leaders of the Shaanxi Research Association for Women and Family (SRAWF) felt they had benefitted from their personal relationship with the Shaanxi Women's Federation and were permitted to run training sessions on domestic violence for police staff as well as members of the Shaanxi People's Congress (Du et al. 2015). The presence of activists within state bodies is also seen by activists as effective. The Indonesian activist Tumbu Saraswati was elected to Parliament as a member of the political party led by the former President Megawati in 2001-04, after having been an activist for women's rights for many years, especially on violence against women. In her opinion, this double role enabled her to voice the claims of the JANKGA PKTP within the Parliament (Eddyono et al. 2016).

The way a claim is framed - that is, expressed - is equally important in negotiating with the state. While in Indonesia, the principle of supporting family life was used to gain support from religious organisations (Eddyono et al. 2016), the SRAWF in China found it very effective to frame domestic violence as a threat to the family and social harmony, to gain the support of Chinese policymakers (Du et al, 2015). In their narrative, offered during the process of our research, domestic violence prevents family harmony and consequently the harmony of society as a whole, making it a matter of concern for the state, instead of leaving it to the private sphere.

Professionals like lawyers and scholars are crucial for framing demands in the legal-technical language used by state actors. The feminist lawyers of the JANKGA PKTP drafted the first bill of the 
national law on domestic violence and submitted it to the National Commission on Violence against Women, in Indonesia in 2002. The scholars of the Chinese ADVN collected rigorous academic evidence on the impact of domestic violence across the country, from 1993 onwards. In India, mobilisation against rape really began with an open letter sent by four lawyers to the Indian Supreme Court that released the policemen accused of raping a young girl called Mathura in 1978. The letter, written in technical terms, argued against the final verdict of the Supreme Court using existing laws and became the manifesto of the national mobilization.

\section{Seeking support from outside}

Additional support for women's mobilization on violence against women can come from international and transnational organizations. Across the three countries, they play different roles. Firstly, these organizations fund initiatives or women's organizations, especially in Indonesia and in China. A wide range of organizations supported women's mobilization in the two countries: international organizations, transnational NGOs, development agencies, and private foundations. Nevertheless, funding is increasingly focused on activities catering to material needs rather than providing support for political mobilization and advocacy (Blackburn, 2004). These choices particularly affect Indonesian grassroots organizations, which rely heavily on international funding.

Secondly, international organizations spread ideas, norms, and promote policy instruments. For example, the Fourth International Women's Conference held at Beijing in 1995 inspired Chinese women activists working on domestic violence. In the view of activists participating in our research, the encounter with women's organizations and activists from other countries helped them discover new forms of organizing and mobilizing, ways of framing their claims, and approaches to violence against women. All of these enabled them to mobilize more effectively on this issue. In India, international actors have less influence on discourses of violence against women, given the maturity of the Indian women's movement and the long history of mobilisation. Also several experiences of violence (in the form of caste violence) are particular to the country, and indeed to specific groups within the country, which makes local activism which retains clarity around its own contextual framing of claims particularly critical. Activists in India made this point while emphasising that they are part of international solidarity groups and networks.

Finally, women's movements, especially in China and in Indonesia, employ international declarations and frameworks to pressure the state to legislate on violence against women. The Convention on the Elimination of all Forms of Discrimination Against Women (CEDAW) and its reporting system is the most used instrument. In November 2014, a group of Chinese women's organizations presented a shadow report to the CEDAW Committee. They described the incidence of domestic violence and advocated national legislation on the matter, claims that were recommended by the Committee in its final report to the Chinese government (Due et al. 2015).

\section{Conclusion}


This article has explored how women have mobilized to successfully articulate and channel claims related to violence against women into the policy agenda in three specific cases: the reform of the sexual assault laws in India; the approval of the Law on Domestic Violence, no. 23/2004 in Indonesia; and the recent approval (December 2015) of the national law on domestic violence in China. It also analysed why other claims related to violence against women, such as the criminalization of marital rape, or impunity of some state actors who commit violence, tend to remain excluded, in spite of women's mobilization.

Our analysis of the recent legal reforms related to violence against women in China, India, and Indonesia provides evidence that change on this issue is a complex process, due to differences within the women's movements, the nature of the state, and the power relations that shape the policy space. Therefore, change not only requires the strong presence of, and mobilization by, women's organizations, but it also requires them to weave broad alliances with the rest of civil society and identify appropriate political opportunities and structures to enable interaction with state actors. Their framing of claims, strategies, and channels to place those claims within the public and the political domains need to be strongly contextual.

In addition, negotiation and bargaining over claims characterize the processes of change. Not only do women's movements negotiate their claims with state actors, but negotiations also take place amongst women's organizations and with other civil society organizations. How women frame their demands is crucial in building consensus, and in consolidating the support from other actors. The country studies presented in this article show that mobilization on claims concerning women as women - gender status - achieves greater results. On the other hand, claims related to violence against women that challenge the patriarchal and heteronormative structures are often left behind, both by women's organizations and by state actors. However, as the process of change is iterative and incremental, the exclusion of certain claims should not be interpreted simply as a failure, but as a step in a longer process of struggle for gender equality.

Finally, while pointing to the complexity of progressive change, the research opens questions on how women's movements could also play a critical role in making their states accountable towards implementing these legal frameworks. Legal change is important as an enabling environment for gender justice, it needs to be backed up by mechanisms and resources for implementation.

Paola Cagna was Research Analyst for the project, based at the United Nations Research Institute for Social Development

\section{Nitya Rao is Professor, Gender and Development, at University of East Anglia}

\section{Endnotes}

(1) Further details and open access publications are available at http://www.unrisd.org/gender-claims 
(2) UNRISD research reports published: Chigateri et al. (for India), and Eddyono et al. (for Indonesia); and forthcoming for China: Du et al.

(3) The All China Women's Federation (ACWF) is the women's organization established by the Chinese Communist Party in 1949. Although it has currently the status of NGO, its long relationship with the party makes it the official spokesperson for matters concerning women's rights. The ACWF has offices at provincial, municipal, and village levels, called Women's Federations. However, an increasing number of women activists have established other organizations labelled as 'autonomous' to differentiate them from the ACWF.

(4) LGBTI denotes lesbian, gay, bisexual, transgender and intersex people.

(5) In November 2015, the proportion of seats held by women in national parliaments is 23.4 per cent in China, around 12 per cent in India, and 17.1 per cent in Indonesia. In Indonesia, the women in parliament at the moment of approving the Law on Domestic Violence, no.23/2004 represented 11.1 per cent of the total seats. In India, during the reform of the Criminal Law in 2013, around 11 per cent of the members of parliament were women. Source: Inter-Parliamentary Union, http://www.ipu.org/wmn-e/classif.htm (accessed on 14 January 2016).

(6) The Emergency was a period between 1975-77, when the then-Indian Prime Minister Indira Gandhi unilaterally declared a state of emergency, suspending all civil rights. During this period, many cases of state repression and harassment against civil society activists were recorded.

(7) The Fatayat Nahdatul Ulama is the young women's branch of the Nahdatul Ulama, an Indonesian Muslim mass organization. Established in 1950, it currently runs programmes on reproductive health, on the eradication of human trafficking and domestic violence.

(8) In May 1998, a series of riots against the Suharto regime escalated across Indonesia. Cases of gang rape against women of Chinese ethnicity and perpetuated by civilians and military forces were uncovered after these events.

\section{References}

Aisyiyah, 2014. Isu-Isu Perempuan dan Anak Perspektif Tarjih Muhammadiyah Menuju Keluarga Sakinah [Women and Children from Tarjih Muhammadiyah's Perspective on Harmonious Families]. Yogyakarta, Indonesia: Aisyiyah

Blackburn, S. 2004. Women and the State in Modern Indonesia. Cambridge: Cambridge University Press.

Chigateri, Shraddha, Mubashira Zaidi and Anweshaa Ghosh. (2016) "Locating the Processes of Policy Change in the Context of Anti-Rape and Domestic Worker Mobilizations in India." UNRISD

Research Report. Geneva: United Nations Research Institute for Social Development. http://www.unrisd.org/80256B3C005BCCF9/\%28httpPublications\%29/03AB499766D6FDB2C125 7F9B004F6BDF?OpenDocument, last accessed 20 May 2016.

Cornwall, Andrea. 2002. "Making Spaces, Changing Places: Situating Participation in Development." IDS Working Paper 170. Brighton: Institute of Development Studies. 
Du, Jie, Dongling, Ma, and Yang, Rujun (2015). Case studies of anti-domestic violence advocacy in China. Background paper prepared for UNRISD research 'When and Why do States Respond to Women's Claims? Understanding Gender-Egalitarian Policy Change in Asia'. Geneva: United Nations Research Institute for Social Development.

Eddyono, S. W. (2005). Women access to justice for women's human rights violation in the domestic shpere in Indonesia; learning from international experiences. (Master of Law), The University of Hong Kong.

Eddyono, Sri Wiyanti, Farha Ciciek Estu Fanani Haiziah Ghazali Yurra Maurice, Dini Anitasari Sabaniah, and Sisillia Velayati. (2016) "When and Why do State Respond to Women's Claims? Understanding Gender-Egalitarian Policy Change in Indonesia." UNRISD Research Report. Geneva: United Nations Research Institute for Social Development.

Eyben, Rosalind. 2012. "The Hegemony Cracked: The Power Guide to Getting Care onto the Development Agenda." IDS Working Paper 411. Brighton: Institute of Development Studies.

Franceschet, Susan. 2010. "Explaining Domestic Violence Policy Outcomes in Chile and Argentina." Latin American Politics and Society 52 (3): 1-29.

Fraser, Nancy. 1989. Unruly Practices: Power, Discourse, and Gender in Contemporary Social Theory. Minneapolis: University of Minnesota Press.

Gaventa, John. 2006. "Finding the Spaces for Change: A Power Analysis." IDS Bulletin 37 (6): 2333.

Gaventa, John, and Rosemary McGee. 2010. Citizen Action and National Policy Reform: Making Change Happen. London and New York: Zed Books.

Htun, Mala, and S. Laurel Weldon. 2010. "When Do Governments Promote Women's Rights? A Framework for the Comparative Analysis of Sex Equality Policy." Perspectives on Politics 8 (01): 207-16.

Htun, Mala, and S. Laurel Weldon. 2012. "The Civic Origins of Progressive Policy Change: Combating Violence against Women in Global Perspective, 1975-2005." American Political Science Review 106 (3): 548-69.

Kumar, R. (1993). The history of doing, Kali for Women, New Delhi.

Mazur, Amy G. 2002. Theorizing Feminist Policy. Oxford: Oxford University Press.

Menon, N. (2014) 'The Conundrum of Agency', Seminar, Issue date January 30 2014, available at http://india-seminar.com/semsearch.htm, last accessed 6 January 2016.

Merry, Sally Engle. 2011. Gender Violence: A Cultural Perspective. Malden, Mass: Wiley-Blackwell. 
Patel, V. (2012) ‘Campaign against Rape by Women's Movement in India', Feminist Network 4.3 $1-16$

Women against Sexual Violence and State Repression (WSS) (2013) Representation to the Justice Verma Commission, 5 January 2013 available at http://wssnet.org/2013/01/05/represenation-to-thejustice-verma-commission/, last accessed 6 January 2016. 